\title{
INVESTIGATION OF SPHINGOSIN-1-PHOSPHATE- TRIGGERED MATRIPTASE ACTIVATION USING A RAT PRIMARY HEPATOCYTE MODEL
}

\author{
Réka Fanni BARNA*, Judit Mercédesz Pomothy, Zsuzsanna PARÉJ \\ and Erzsébet PÁSZTINÉ GERE \\ Department of Pharmacology and Toxicology, University of Veterinary Medicine \\ Budapest, István u. 2, H-1078 Budapest, Hungary
}

(Received 13 August 2019; accepted 15 October 2019)

\begin{abstract}
Sphingosine-1-phosphate (S1P) has been reported as a matriptase activator. The aim of this study was to reveal if S1P can influence hepcidin production. Furthermore, we investigated how S1P can affect the viability and the redox status of primary hepatocytes. Rat primary hepatocytes were cultivated for $72 \mathrm{~h}$ and were treated with 50, 200, $1000 \mathrm{ng} / \mathrm{ml} \mathrm{S1P}$. Cell-free supernatants were collected every $24 \mathrm{~h}$. Cell viability was tested by a colorimetric method using tetrazolium compound (MTS). The hepcidin levels in the cell-free supernatants were examined with hepcidin sandwich ELISA to determine the effect of S1P on the hepcidin-modulating ability of matriptase. In order to estimate the extent of S1Pgenerated oxidative stress, extracellular $\mathrm{H}_{2} \mathrm{O}_{2}$ measurements were performed by the use of fluorescent dye. Based on the findings, S1P treatment did not cause cell death for $72 \mathrm{~h}$ at concentrations up to $1000 \mathrm{ng} / \mathrm{ml}$. S1P did not influence the extracellular $\mathrm{H}_{2} \mathrm{O}_{2}$ production for $72 \mathrm{~h}$. The hepcidin levels were significantly suppressed in hepatocytes exposed to S1P treatment. Further studies would be needed to explore the exact mechanism of action of S1P.
\end{abstract}

hepatocytes

Key words: Matriptase, hepcidin, sphingosine-1-phosphate, rat primary

The major internal detoxification organ in mammals is the liver, which serves a wide spectrum of vital functions. Liver cells are divided into hepatocytes, Kupffer cells, and endothelial cells. Transformed hepatocyte cell lines, for example rat hepatoma H-4-II-E cells (Kovacs et al., 1977) cannot adequately mimic the phenotype of the liver. In contrast, the primary cells were isolated directly from the tissues and therefore have a normal cell morphology and are ca-

*Corresponding author; E-mail: Barna.Reka.Fanni@univet.hu; Phone: 0036 (1) 478-4100/ext. 8569

Open Access. This is an open-access article distributed under the terms of the Creative Commons AttributionNonCommercial 4.0 International License (https://creativecommons.org/licenses/by-nc/4.0/), which permits unrestricted use, distribution, and reproduction in any medium for non-commercial purposes, provided the original author and source are credited, a link to the CC License is provided, and changes - if any - are indicated. 
pable of maintaining many of the markers and functions seen in vivo (Pan et al., 2009). The rat primary hepatocyte model is an important tool for hepatic toxicology studies. However, it is well reported that primary cells have a limited lifetime (2-4 days) (Soldatow et al., 2013).

Matriptase-1 (MT-1, also known as epithin) and matriptase-2 (MT-2, also known as TMPRSS6) belong to the type II transmembrane serine protease family (TTSP) (Hooper et al., 2001), more precisely to the matriptase subfamily (Szabo and Bugge, 2008). MT-1 is widely expressed in epithelial tissues, with high levels in the gastrointestinal tract, prostate (Takeuchi et al., 1999), normal and cancerous breast, ovarian and colon tissues (Oberst et al., 2003). MT-1 is required for postnatal survival. According to Oberst et al. (2001), MT-1 has a potential role in cancer invasion and metastasis in some types of cancer.

MT-2 has been found in high levels in the liver and in small amounts in the kidney (Hooper et al., 2003). MT-2 is structurally similar to MT-1 (Sanders et al., 2010). Silvestri et al. (2008) identified the membrane-bound haemojuvelin as a substrate for MT-2 in vitro. MT-2 can regulate the iron homeostasis (Folgueras et al., 2008). Hepcidin is a systemic iron regulatory hormone, secreted by the liver (Du et al., 2008). It modulates the iron absorption via duodenal enterocytes (Nicolas et al., 2001). Hepcidin negatively regulates the iron export by promoting the degradation of ferroportin, which is an iron exporter located on the surface of intestinal enterocytes, macrophages, and hepatocytes (Nemeth et al., 2004). MT2 cleaves membrane-bound haemojuvelin which is the main activator of hepcidin transcription (Silvestri et al., 2008). Dysfunction of matriptase-2 (MT-2) can be involved in iron regulatory disorders via altered regulation of hepcidin expression.

Both MT-1 and MT-2 are anchored to the cell surface (Takeuchi et al., 2000; Hooper et al., 2003) and can undergo autocatalytic activation in vitro (Takeuchi et al., 1999; Ramsay et al., 2009).

Sphingosine-1-phosphate (S1P) is a bioactive sphingolipid metabolite. Most cells can synthesise S1P which is an intracellular second messenger and extracellular mediator in mammalian cells (Yatomi et al., 2001). S1P regulates a wide variety of biological responses, for example angiogenesis, vascular maturation, cardiac development and immunity, and is important for cell proliferation, cell survival and cell movement. There are five G-protein-coupled S1P receptors which enable regulation of numerous downstream signalling pathways. The role of S1P depends on the relative expression of these receptors (Spiegel and Milstien, 2003). Benaud et al. (2002) determined a novel biological function of S1P as an activator of matriptase in epithelial cells. It was also demonstrated that bioactive phospholipids can activate cell surface proteases (Benaud et al., 2002).

The aim of this study was to investigate the possible relationship between S1P and hepcidin production in a rat primary hepatocyte model. Firstly, we estimated the cytotoxic properties of S1P and then we also investigated the effect of $\mathrm{S} 1 \mathrm{P}$ on baseline extracellular $\mathrm{H}_{2} \mathrm{O}_{2}$ production. The changes in hepcidin levels in cell-free supernatants were also quantified. 


\section{Materials and methods}

\section{Cells and culture conditions}

Cryopreserved primary rat hepatocytes, isolated from male Sprague-Dawley rats, were purchased from Thermo Fisher Scientific (Waltham, Massachusetts, USA). Cryopreserved cells were thawed at $37^{\circ} \mathrm{C}$, pipetted into hepatocyte thaw medium (Thermo Fisher Scientific, Waltham, Massachusetts, USA) and centrifuged with $100 \times \mathrm{g}$ for $10 \mathrm{~min}$. Hepatocytes were seeded on membrane insert plate (Costar Transwell permeable supports, $0.4 \mu \mathrm{m}$ polyester membrane $24 \mathrm{~mm}$ insert, 6-well plate, tissue culture treated, Merck, Germany) or 96-well plate (Merck, Darmstadt, Germany). The seeding density was $0.9-1.1 \times 10^{6}$ cells $/ \mathrm{ml}$, in $2 \mathrm{ml}$ apical medium. Before seeding the cells, viability was checked by Trypan blue staining (1:8 dilutions, 1 min, Merck, Germany). The maintenance medium was Williams E medium (Thermo Fisher Scientific, USA) supplemented with $10,000 \mathrm{IU} / \mathrm{ml}$ penicillin, $10 \mathrm{mg} / \mathrm{ml}$ streptomycin, $2 \mathrm{mM}$ glutamine, $0.2 \mathrm{IU} / \mathrm{ml}$ insulin, $4 \mu \mathrm{g} / 1$ dexamethasone, and $0.22 \%$ bicarbonate. Fetal bovine serum $(10 \% \mathrm{FBS})$ was added to the medium only in the first $6 \mathrm{~h}$ after thawing. The maintenance medium without FBS was then used and replaced every $24 \mathrm{~h}$. The cells were incubated at $37{ }^{\circ} \mathrm{C}, 5 \% \mathrm{CO}_{2}$.

\section{Exposure of primary hepatocytes to SIP}

S1P was purchased from Bio-Techne (Minneapolis, Minnesota, United States). S1P was dissolved in phosphate-buffered saline with $4 \mathrm{mg} / \mathrm{ml}$ bovine serum albumin, which was the stock solution $(0.5 \mathrm{mg} / \mathrm{ml})$. After the first $6 \mathrm{~h}, \mathrm{~S} 1 \mathrm{P}$ was added to the medium apically at 50,200 or $1000 \mathrm{ng} / \mathrm{ml}$. The maintenance medium with S1P was changed every $24 \mathrm{~h}$. The treatment time was $72 \mathrm{~h}$.

\section{MTS assay for cell viability}

The hepatocytes were seeded in a 96-well plate and incubated with 50, 200 or $1000 \mathrm{ng} / \mathrm{ml} \mathrm{S1P}$ for $72 \mathrm{~h}$. The control wells were incubated with maintenance medium only. After the medium was removed, $100 \mu \mathrm{l}$ maintenance medium was added with $20 \mu 1$ CellTiter96 aqueous one solution (Promega, Bioscience, Hungary) in every well. This reagent contained the tetrazolium compound MTS (Cory et al., 1991). The assay protocol is based on the reduction of the MTS tetrazolium compound by viable cells to generate a coloured formazan dye that is soluble in cell culture media. This conversion is reported to be carried out by $\mathrm{NAD}(\mathrm{P}) \mathrm{H}$-dependent dehydrogenase enzymes in metabolically active cells. The cells were incubated with the dye for $2 \mathrm{~h}$ at $37{ }^{\circ} \mathrm{C}, 5 \% \mathrm{CO}_{2}$. The absorbance of formazan was measured by EZ Read Biochrom 400 microplate reader at $490 \mathrm{~nm}$ wavelength (Biochrom Ltd., UK). 


\section{Amplex Red assay for extracellular $\mathrm{H}_{2} \mathrm{O}_{2}$ level measurement}

Amplex Red Hydrogen Peroxide Assay Kit (Thermo Fisher Scientific, USA) was used to measure the concentration of $\mathrm{H}_{2} \mathrm{O}_{2}$ in cell-free supernatant from the apical compartment. Fluorescence ROS measurement was based on the fact that Amplex Red reagent reacts with $\mathrm{H}_{2} \mathrm{O}_{2}$ and horseradish peroxidase and it is converted into fluorescent resorufin. The cells were treated with 50, $200 \mathrm{or} 1000 \mathrm{ng} /$ $\mathrm{ml} \mathrm{S1P}$ for $72 \mathrm{~h}$. The samples were collected every $24 \mathrm{~h} ; 50 \mu \mathrm{l}$ cell-free supernatant and $50 \mu \mathrm{l}$ Amplex Red working solution was used to determine the $\mathrm{H}_{2} \mathrm{O}_{2}$ concentration. After $30 \mathrm{~min}$ of incubation at room temperature the samples were measured with Victor X2 2030 fluorometer at $560 \mathrm{~nm}$ excitation and $590 \mathrm{~nm}$ emission wavelength.

\section{Hepcidin sandwich ELISA for determination of hepcidin level}

To determine the concentration of hepcidin in the apical compartment from the cell-free supernatant, we used a rat hepcidin ELISA kit from Elabscience Biotechnology (Houston, Texas, USA). After 24, 48 and $72 \mathrm{~h}$ of S1P treatment at 50,200 or $1000 \mathrm{ng} / \mathrm{ml}$ concentrations, the apical cell-free supernatants were collected. The assay procedure was performed according to the manufacturer's guidelines. The absorbance values were detected with EZ Read Biochrom 400 microplate reader at $450 \mathrm{~nm}$ wavelength (Biochrom Ltd, UK).

\section{Statistical analysis}

Differences between groups were statistically analysed using one-way analysis of variance (ANOVA) with Tukey's post hoc test, where the data were of normal distribution and the homogeneity of variances was confirmed. Statistical significance was set at $\mathrm{P}<0.05$. For statistical evaluation the $\mathrm{R} 2.14 .2$ software package was applied (2012, Vienna, Austria). The results are expressed as means \pm SDs.

\section{Results}

\section{The effect of S1P on cell viability}

It was confirmed that even the highest concentration of S1P (at $1000 \mathrm{ng} /$ $\mathrm{ml})$ did not cause significant cell death after $24-\mathrm{h}(\mathrm{P}=0.96887)$ and $72-\mathrm{h}(\mathrm{P}=$ 0.1960) treatment (Fig. 1). It was found that S1P administration for $72 \mathrm{~h}$ even at $1000 \mathrm{ng} / \mathrm{ml}$ was safe in the case of the rat primary hepatocyte model. 


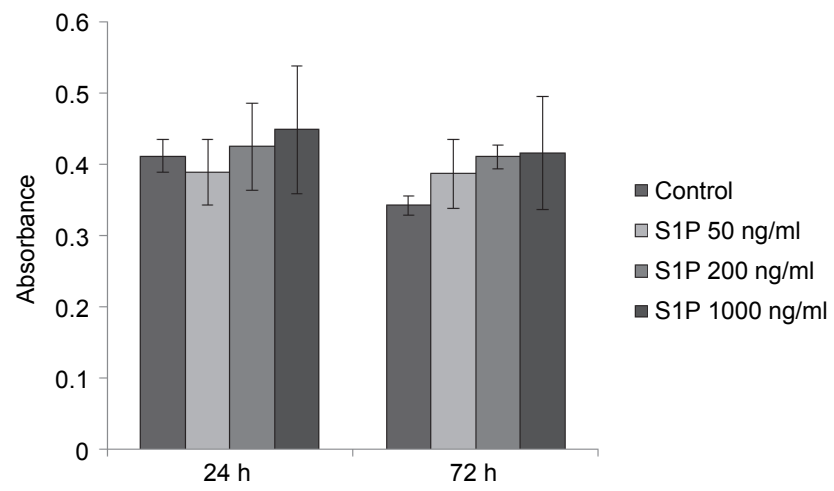

Fig. 1. Assessment of cell viability after 24 and $72 \mathrm{~h}$ of incubation of rat primary hepatocytes with $\mathrm{S} 1 \mathrm{P}$ at 50, 200 and $1000 \mathrm{ng} / \mathrm{ml}$. The results represent average absorbance values of produced MTS formazan \pm standard deviations. No significant differences were found between control and $\mathrm{S} 1 \mathrm{P}$ - treated cells after 24 and $72 \mathrm{~h}$ of incubation. The results are representative of three independent experiments

\section{The assessment of $\mathrm{H}_{2} \mathrm{O}_{2}$ measurement}

We found that S1P did not cause a significant increase in the extracellular $\mathrm{H}_{2} \mathrm{O}_{2}$ levels at any applied concentrations within the investigated time period $(\mathrm{P}>0.05$ in each case) (Fig. 2).

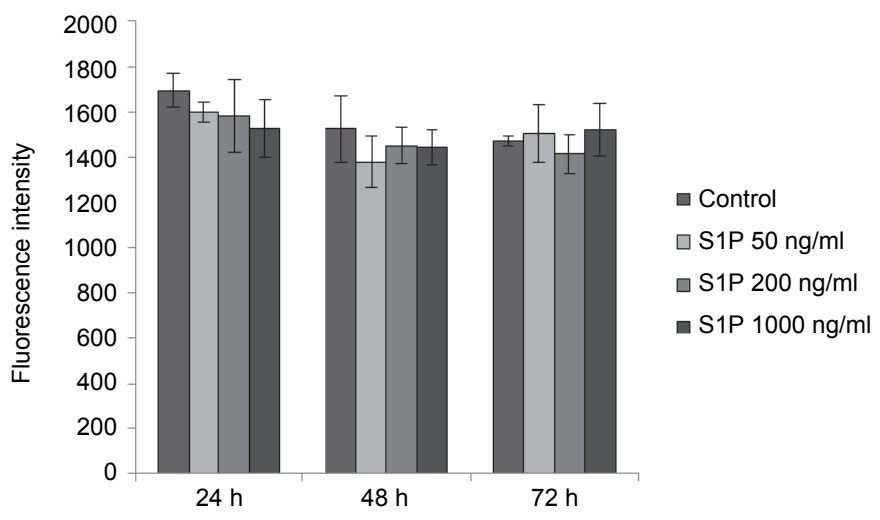

Fig. 2. The effects of S1P at 50, 200 and $1000 \mathrm{ng} / \mathrm{ml}$ on extracellular $\mathrm{H}_{2} \mathrm{O}_{2}$ production of rat primary hepatocytes. Cells were exposed to S1P for 24, 48 and $72 \mathrm{~h}$. No significant differences were found between the control and the S1P-treated groups. The values represent the means of resorufin fluorescence intensities \pm standard deviations $(n=3)$

\section{S1P-caused changes in hepcidin levels}

It was found that the hepcidin levels in cell-free supernatants were significantly decreased compared to control samples after $24 \mathrm{~h}$ of incubation at each concentration of S1P (at $50 \mathrm{ng} / \mathrm{ml}$ and $200 \mathrm{ng} / \mathrm{ml}: \mathrm{P}<0.001$, at $1000 \mathrm{ng} / \mathrm{ml}: \mathrm{P}<$ 
$0.01)$. Hepcidin production was significantly reduced when cells were treated with S1P at $200 \mathrm{ng} / \mathrm{ml}(\mathrm{P}=0.0206)$ and $1000 \mathrm{ng} / \mathrm{ml}(\mathrm{P}<0.001)$ after $48 \mathrm{~h}$ of incubation (at $50 \mathrm{ng} / \mathrm{ml}: \mathrm{P}=0.8656$ ). After $72-\mathrm{h}$ administration of S1P, there were significant differences in hepcidin levels between the treated and the control samples (in the case of S1P at $50 \mathrm{ng} / \mathrm{ml}: \mathrm{P}=0.00124$, in the case of S1P at $200 \mathrm{ng}$ / $\mathrm{ml}$ and at $1000 \mathrm{ng} / \mathrm{ml}: \mathrm{P}<0.001$ ) (Fig. 3).

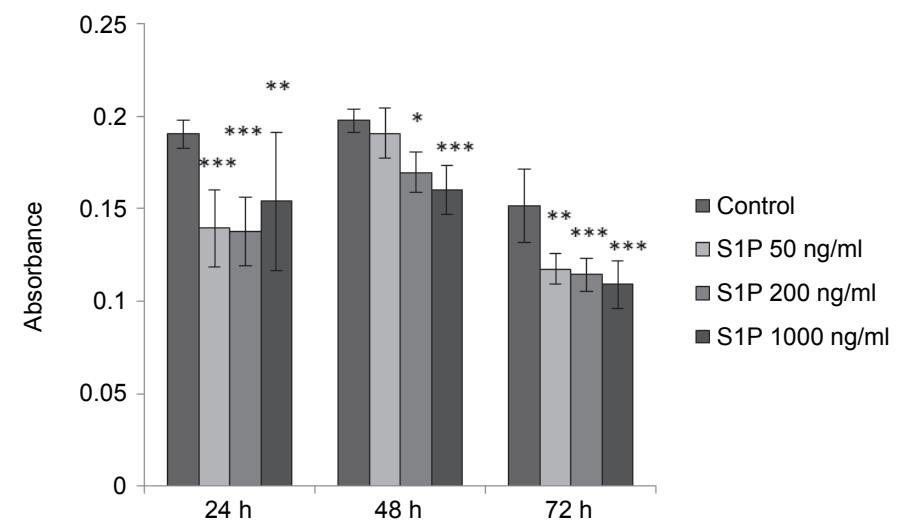

Fig. 3. Absorbance values of hepcidin in rat primary hepatocytes exposed to S1P for 24, 48 and $72 \mathrm{~h}$. The hepcidin levels in the cell-free supernatant were significantly decreased after $24 \mathrm{~h}$ of incubation at all concentrations of S1P $(50 \mathrm{ng} / \mathrm{ml}$ and $200 \mathrm{ng} / \mathrm{ml}: \mathrm{P}<0.001,1000 \mathrm{ng} / \mathrm{ml}: \mathrm{P}<0.01)$.

After $48 \mathrm{~h}$ incubation time S1P at $200 \mathrm{ng} / \mathrm{ml}(\mathrm{P}=0.0206)$ and at $1000 \mathrm{ng} / \mathrm{ml}(\mathrm{P}<0.001)$

significantly decreased the hepcidin levels. The hepcidin levels were significantly lower in the

$\mathrm{S} 1 \mathrm{P}$-treated groups after $72 \mathrm{~h}$ of incubation (at $50 \mathrm{ng} / \mathrm{ml}: \mathrm{P}=0.00124$, at $200 \mathrm{ng} / \mathrm{ml}$ and $1000 \mathrm{ng} / \mathrm{ml}: \mathrm{P}<0.001)$ compared to control values. Data are presented as means of absorbance \pm standard deviations $(\mathrm{n}=3)$. ${ }^{* * *} \mathrm{P}<0.001, \stackrel{* *}{\mathrm{P}}<0.01,{ }^{*} \mathrm{P}<0.05$

\section{Discussion}

MT-1 has an important role in regulating the formation and integrity of the intestinal epithelial barrier (Buzza et al., 2010), development of the epidermis, hair follicles, and cellular immune system, and it is required for postnatal survival (List et al., 2002) via tight junction regulation. S1P as an extracellular mediator and intracellular second messenger can activate MT-1 in nanomolar concentrations (Benaud et al., 2002).

In our earlier study, S1P was tested on IPEC-J2 non-tumorigenic cell line (Pászti-Gere et al., 2016). IPEC-J2 was isolated from the jejunum of a neonatal non-suckled piglet (Berschneider, 1989). The main advantages of IPEC-J2 cells were that they possess enterocyte-like microvilli and tight junctions (Schierack et al., 2006). Occludin, claudin- $1,-3,-4,-5,-7$, and -8 were also detected (Zakrzewski et al., 2013) in IPEC-J2 cells. Thus, the IPEC-J2 cell line more closely mimics in vivo conditions than other, tumorigenic cell lines (Vergauwen, 2015). In our pre- 
vious study it was found that $\mathrm{S} 1 \mathrm{P}$ at $200 \mathrm{ng} / \mathrm{ml}$ concentration was not cytotoxic and did not cause an elevation in extracellular hydrogen peroxide levels. S1P had strong barrier protective effect, since the transepithelial electrical resistance was elevated and a higher amount of occludin appeared in cell membranes (PásztiGere et al., 2016).

MT-2 regulates the iron homeostasis via cleavage of membrane-bound haemojuvelin, which is a main activator of hepcidin transcription (Silvestri et al., 2008). Hepcidin inhibits the entry of iron into the plasma and its absorption from enterocytes. It was also observed that mice with a TMPRSS6 -/- defect or the absence of matriptase-2 proteolytic activity have iron deficiency anaemia, upregulation in hepcidin transcription, and reduced protein levels of ferroportin on enterocytes (Du et al., 2008; Folgueras et al., 2008). Thus, stimulation of MT-2 activation could be an alternative treatment of iron deficiency anaemia.

Our aim was to elucidate the effects of S1P on MT-2 indirectly via monitoring hepcidin levels on rat primary hepatocytes. S1P regulates numerous downstream signalling pathways, for example cell proliferation, survival and cell motility (Spiegel and Milstien, 2003). The role of S1P was examined using several different cells. In the liver the modulation of S1P can be a potential therapeutic target for the treatment of several hepatic diseases. It was observed that sphingolipid metabolites produce a significant upregulation of long-chain ceramides in the serum of patients with hepatocellular carcinoma (HCC) as compared to patients with cirrhosis (Grammatikos et al., 2016). In contrast, S1P (between concentrations of 10 and $30 \mu \mathrm{M}$ ) reduced the HCC cell migration induced by hepatocyte growth factor in $\mathrm{HuH} 7$ cells (Matsushima-Nishiwaki et al., 2018). In mice, the S1P level and the expression of one of its receptors (S1P3) in the liver were up-regulated in cholestasis-induced liver fibrosis (Li et al., 2009). Two animal models of type 1 diabetes had elevated S1P levels compared to control mice (Fox et al., 2011). However, the role of S1P in hepatic dysfunctions has not been completely clarified yet.

On the one hand, S1P could elevate $\mathrm{H}_{2} \mathrm{O}_{2}$ level in FRTL-5 thyroid cells (Okajima et al., 1997), while on the other hand Nakahara et al. (2012) described that S1P can inhibit the apoptosis of granulosa cells.

Rat primary hepatocytes represent the in vivo conditions better than a hepatoma cell line, therefore the modulating effect of S1P on matriptase activity can be better predicted. According to our findings, S1P, in the tested concentration range, did not affect cell viability and extracellular $\mathrm{H}_{2} \mathrm{O}_{2}$ levels significantly. Based on our results, the hepcidin levels significantly decreased in rat primary hepatocytes exposed to S1P after an incubation time of 24, 48 and $72 \mathrm{~h}$.

In conclusion, the application of S1P seems to be safe at 50, 200 and $1000 \mathrm{ng} / \mathrm{ml}$ concentrations, because it did not increase the cell death rate of hepatocytes and did not disturb redox cell status. S1P treatment led to decreased hepcidin production; however, the changes in hepcidin levels were not fully de- 
pendent on S1P concentration. The results of this study indicate the beneficial properties of S1P in the treatment of disturbed iron homeostasis.

\section{Acknowledgements}

This research was supported by the Hungarian Scientific Research Fund [grant numbers: 115685 and 124522]. This project was supported by the János Bolyai Research Scholarship of the Hungarian Academy of Sciences. This work is supported by the European Union and co-financed by the European Social Fund (grant agreement no. EFOP3.6.1-16-2016-00024, EFOP-3.6.2-16-2017-00012). Supported by the ÚNKP-18-3 New National Excellence Program of the Ministry of Human Capacities.

\section{References}

Benaud, C., Oberst, M., Hobson, J. P., Spiegel, S., Dickson, R. B. and Lin, C. Y. (2002): Sphingosine-1-phosphate, present in serum-derived lipoproteins, activates matriptase. J Biol Chem. 277, 10539-10546.

Berschneider, H. M. (1989): Development of normal cultured small intestinal epithelial cell lines which transport $\mathrm{Na}$ and $\mathrm{Cl}$. Gastroenterology 96, A41.

Buzza, M. S., Netzel-Arnett, S., Shea-Donohue, T., Zhao, A., Lin, C. Y., List, K., Szabo, R., Fasano, A., Bugge, T. H. and Antalis, T. M. (2010): Membrane-anchored serine protease matriptase regulates epithelial barrier formation and permeability in the intestine. Proc. Natl Acad. Sci. USA 107, 4200-4205.

Cory, A. H., Owen, T. C., Barltrop, J. A. and Cory, J. G. (1991): Use of an aqueous soluble tetrazolium/formazan assay for cell growth assays in culture. Cancer Commun. 3, 207-212.

Du, X., She, E., Gelbart, T., Truksa, J., Lee, P., Xia, Y., Khovananth, K., Mudd, S., Mann, N., Moresco, E. M., Beutler, E. and Beutler, B. (2008): The serine protease TMPRSS6 is required to sense iron deficiency. Science 320, 1088-1092.

Folgueras, A. R., de Lara, F. M., Pendás, A. M., Garabaya, C., Rodríguez, F., Astudillo, A., Bernal, T., Cabanillas, R., López-Otín, C. and Velasco, G. (2008): Membrane-bound serine protease matriptase-2 (Tmprss6) is an essential regulator of iron homeostasis. Blood 112, 25392545.

Fox, T. E., Bewley, M. C., Unrath, K. A., Pedersen, M. M., Anderson, R. E., Jung, D. Y., Jefferson, L. S., Kim, J. K., Bronson, S. K., Flanagan, J. M. and Kester, M. (2011): Circulating sphingolipid biomarkers in models of type 1 diabetes. J. Lipid Res. 52, 509-517.

Grammatikos, G., Schoell, N., Ferreirós, N., Bon, D., Herrmann, E., Farnik, H., Köberle, V., Piiper, A., Zeuzem, S., Kronenberger, B., Waidmann, O. and Pfeilschifter, J. (2016): Serum sphingolipidomic analyses reveal an upregulation of C16-ceramide and sphingosine-1phosphate in hepatocellular carcinoma. Oncotarget. 7, 18095-18105.

Hooper, J. D., Campagnolo, L., Goodarzi, G., Truong, T. N., Stuhlmann, H. and Quigley, J. P. (2003): Mouse matriptase-2: identification, characterization and comparative mRNA expression analysis with mouse hepsin in adult and embryonic tissues. Biochem. J. 373, 689-702.

Hooper, J. D., Clements, J. A., Quigley, J. P. and Antalis, T. M. (2001): Type II transmembrane serine proteases. J. Biol. Chem. 276, 857-860.

Kovacs, C. J., Evans, M. J. and Hopkins, H. A. (1977): Properties of the H-4-II-E tumor cell system. II. In vitro characteristics of an experimental tumor cell line. Cell Tissue Kinet. 10, $245-254$. 
Li, C., Jiang, X., Yang, L., Liu, X., Yue, S. and Li, L. (2009): Involvement of sphingosine 1phosphate (SIP)/S1P3 signaling in cholestasis-induced liver fibrosis. Am. J. Pathol. 175, $1464-1472$.

List, K., Haudenschild, C. C., Szabo, R., Chen, W., Wahl, S. M., Swaim, W., Engelholm, L. H., Behrendt, N. and Bugge, T. H. (2002): Matriptase/MT-SP1 is required for postnatal survival, epidermal barrier function, hair follicle development, and thymic homeostasis. Oncogene 21, 3765-3779.

Matsushima-Nishiwaki, R., Yamada, N., Fukuchi, K. and Kozawa, O. (2018): Sphingosine 1phosphate (S1P) reduces hepatocyte growth factor-induced migration of hepatocellular carcinoma cells via S1P receptor 2. PLoS One 13, e0209050.

Nakahara, T., Iwase, A., Kondo, M., Nakamura, T., Goto, M. and Kikkawa, F. (2012): Sphingosine-1-phosphate inhibits hydrogen peroxide-induced granulosa cell apoptosis via the PI3K/Akt signaling pathway. Fertil. Steril. 98, 1001-1008.

Nemeth, E., Tuttle, M. S., Powelson, J., Vaughn, M. B., Donovan, A., Ward, D. M., Ganz, T. and Kaplan, J. (2004): Hepcidin regulates cellular iron efflux by binding to ferroportin and inducing its internalization. Science 306, 2090-2093.

Nicolas, G., Bennoun, M., Devaux, I., Beaumont, C., Grandchamp, B., Kahn, A. and Vaulont, S. (2001): Lack of hepcidin gene expression and severe tissue iron overload in upstream stimulatory factor 2 (USF2) knockout mice. Proc. Natl Acad. Sci. USA 98, 8780-8785.

Oberst, M., Anders, J., Xie, B., Singh, B., Ossandon, M., Johnson, M., Dickson, R. B. and Lin, C. Y. (2001): Matriptase and HAI-1 are expressed by normal and malignant epithelial cells in vitro and in vivo. Am. J. Pathol. 158, 1301-1311.

Oberst, M. D., Singh, B., Ozdemirli, M., Dickson, R. B., Johnson, M. D. and Lin, C. Y. (2003): Characterization of matriptase expression in normal human tissues. J. Histochem. Cytochem. 51, 1017-1025.

Okajima, F., Tomura, H., Sho, K., Kimura, T., Sato, K., Im, D. S., Akbar, M. and Kondo, Y. (1997): Sphingosine 1-phosphate stimulates hydrogen peroxide generation through activation of phospholipase C-Ca2+ system in FRTL-5 thyroid cells: possible involvement of guanosine triphosphate-binding proteins in the lipid signaling. Endocrinology 138, 220-229.

Pan, C., Kumar, C., Bohl, S., Klingmueller, U. and Mann, M. (2009): Comparative proteomic phenotyping of cell lines and primary cells to assess preservation of cell type-specific functions. Mol. Cell. Proteomics 8, 443-450.

Pászti-Gere, E., Jerzsele, Á., Balla, P., Ujhelyi, G. and Székács, A. (2016): Reinforced epithelial barrier integrity via matriptase induction with sphingosine-1-phosphate did not result in disturbances in physiological redox status. Oxidative Medicine and Cellular Longevity $\mathbf{5}$, 1-7. DOI: 10.1155/2016/9674272.

Ramsay, A. J., Hooper, J. D., Folgueras, A. R., Velasco, G. and López-Otín, C. (2009): Matriptase2 (TMPRSS6): a proteolytic regulator of iron homeostasis. Haematologica 94, 840-849.

Sanders, A. J., Webb, S. L., Parr, C., Mason, M. D. and Jiang, W. G. (2010): The type II transmembrane serine protease, matriptase-2: Possible links to cancer? Anticancer Agents Med. Chem. 10, 64-69.

Schierack, P., Nordhoff, M., Pollmann, M., Weyrauch, K. D., Amasheh, S., Lodemann, U., Jores, J., Tachu, B., Kleta, S., Blikslager, A., Tedin, K. and Wieler, L. H. (2006): Characterization of a porcine intestinal epithelial cell line for in vitro studies of microbial pathogenesis in swine. Histochem. Cell. Biol. 125, 293-305.

Silvestri, L., Pagani, A., Nai, A., De Domenico, I., Kaplan, J. and Camaschella, C. (2008): The serine protease matriptase-2 (TMPRSS6) inhibits hepcidin activation by cleaving membrane hemojuvelin. Cell Metab. 8, 502-511.

Soldatow, V. Y., Lecluyse, E. L., Griffith, L. G. and Rusyn, I. (2013): In vitro models for liver toxicity testing. Toxicol. Res. 2, 23-39.

Spiegel, S. and Milstien, S. (2003): Sphingosine-1-phosphate: an enigmatic signalling lipid. Nat. Rev. Mol. Cell Biol. 4, 397-407. 
Szabo, R. and Bugge, T. H. (2008): Type II transmembrane serine proteases in development and disease. Int. J. Biochem. Cell Biol. 40, 1297-1316.

Takeuchi, T., Harris, J. L., Huang, W., Yani, K. W., Coughlin, S. R. and Craik, C. S. (2000): Cellular localization of membrane-type serine protease 1 and identification of protease-activated receptor-2 and single-chain urokinase-type plasminogen activator as substrate. J. Biol. Chem. 275, 26333-26342.

Takeuchi, T., Shuman, M. A. and Craik, C. S. (1999): Reverse biochemistry: Use of macromolecular protease inhibitors to dissect complex biological processes and identify a membranetype serine protease in epithelial cancer and normal tissue. Proc. Natl Acad. Sci. USA 96, $11054-11061$.

Vergauwen, H. (2015): The IPEC-J2 cell line. In: Verhoeckx, K. et al. (eds) The Impact of Food Bioactives on Health. Springer, Cham. pp. 125-134.

Yatomi, Y., Ozaki, Y., Ohmori, T. and Igarashi, Y. (2001): Sphingosine 1-phosphate: synthesis and release. Prostaglandins Other Lipid Mediat. 64, 107-122.

Zakrzewski, S. S., Richter, J. F., Krug, S. M., Jebautzke, B., Lee, I. F., Rieger, J., Sachtleben, M., Bondzio, A., Schulzke, J. D., Fromm, M. and Gunzel, D. (2013): Improved cell line IPECJ2, characterized as a model for porcine jejunal epithelium. PLoS One 8, e79643.

This is an open-access article distributed under the terms of the Creative Commons Attribution 4.0 International License (https://creativecommons.org/licenses/by/4.0/), which permits unrestricted use, distribution, and reproduction in any medium, provided the original author and source are credited, a link to the CC License is provided, and changes - if any - are indicated. (SID_1) 